Pobrane z czasopisma Annales H - Oeconomia http://oeconomia.annales.umcs.pl

Data: 26/04/2023 11:34:20

DOI:10.17951/h.2021.55.3.117-131

\begin{tabular}{lcc}
\hline \multicolumn{1}{c}{ A N N A L E S } \\
UNIVERSITATIS MARIAE CURIE-SKŁODOWSKA \\
LUBLIN - POLONIA \\
VOL. LV, 3 & SECTIOH H \\
\hline
\end{tabular}

\title{
JULIA SZUTOWSKA
}

julia.szutowska@ue.poznan.pl

Poznań University of Economics and Business. Department of Natural Science and Quality Assurance

Al. Niepodległości 10, 61-875 Poznań, Poland

ORCID ID: https://orcid.org/0000-0001-5819-2015

\section{DANIELA GWIAZDOWSKA}

daniela.gwiazdowska@ue.poznan.pl

Poznań University of Economics and Business. Department of Natural Science and Quality Assurance

Al. Niepodległości 10, 61-875 Poznań, Poland

ORCID ID: https://orcid.org/0000-0002-0972-6225

\section{BOGDAN SOJKIN}

bogdan.sojkin@ue.poznan.pl

Poznań University of Economics and Business. Department of Product Marketing

Al. Niepodległości 10, 61-875 Poznań, Poland

ORCID ID: https://orcid.org/0000-0001-5468-8638

\section{Consumer Behaviour on the Non-Dairy Fermented Market}

Keywords: consumer behaviour; food choice, consumption; purchasing; functional food

JEL: D1; D12; E21

How to quote this paper: Szutowska, J., Gwiazdowska, D., \& Sojkin, B. (2021). Consumer Behaviour on the Non-Dairy Fermented Market. Annales Universitatis Mariae Curie-Skłodowska, sectio HOeconomia, Vol. 55, No. 3. 


\begin{abstract}
Theoretical background: In recent decades, an increase in the consumption of non-dairy fermented products with probiotic potential has been observed. Food choices is a complex process that involves several factors concerning product-related aspects like taste, pro-health values, price or packaging, as well as individual factors (e.g. beliefs) or social issues (e.g. culture, tradition).

Purpose of the article: Therefore, the aim of this study was to understand the food choices, food intake and purchasing habits regarding vegetables fermented products (focusing on preserves and juices) in the reality of the Polish market.

Research methods: The research was conducted in Poland with the use of an original questionnaire among a group of 205 individuals of both genders, aged between 21 and above 60 years old. Also, descriptive statistics, one-way analysis of variance (ANOVA) and post-hoc Tukey's test were used in the data analyses. Main findings: Research findings indicate that fermented vegetable foods are mainly seen as pro-health products characterized by probiotic properties, higher vitamin $\mathrm{C}$ content and associated with the ability to increase human's immunity. Sauerkraut, pickled cucumbers and beetroots are the most frequently and eagerly consumed products. On the other hand, fermented vegetable juices are less popular among respondents. The most crucial factors determining the choice of this product category include taste, pro-health and probiotic properties, nutritional values and product composition.
\end{abstract}

\title{
Introduction
}

In recent days, the popularity of non-dairy fermented products characterized by probiotic properties is increasing, especially among producers of functional foods, food technologists, scientists and health-conscious consumers (Panghal et al., 2018). Although the current probiotic market is dominated by dairy food (mostly yoghurts), non-dairy fermented food products based on fruit and vegetables possess some exclusive features and advantages compared to traditional dairy probiotic food (Ávila et al., 2020; Granato, Branco, Nazzaro, Cruz, \& Faria, 2010). From the point of view of potential customers and producers, these advantages can be divided into health-related and economic issues. Firstly, the main recipients of non-dairy fermented products are consumers struggling with health problems such as lactose intolerance, allergy to cow's milk protein or high cholesterol levels (Kandylis, Pissaridi, Bekatorou, Kanellaki, \& Koutinas, 2016; Kumar, Venkata, \& Vijayendra, 2015). Due to the increasing awareness of environmental protection and healthy eating habits, vegans and vegetarians might be also potential consumers of this product category. In addition, a growing number of scientific papers regarding the positive influence of non-dairy fermented products on human health provides their greater popularity and consumption (Hutkins, 2019).

Numerous scientific reports indicate that beyond basic nutritional properties, fermented products with probiotic potential might be also characterized by their functional features like antidiabetic (Mazlan, Suffian, \& Sharifuddin, 2015) and anti-inflammatory properties (Filannino et al., 2013), stimulation of antitumor activity (Ye, Huang, Terefe, \& Augustin, 2019) also in the treatment of many gastrointestinal disorders (e.g. irritable bowel syndrome or Crohn's disease) (Ranadheera, Vidanarachchi, Rocha, Cruz, \& Ajlouni, 2017). Furthermore, comparing fermented 
fruit and vegetable products to fermented dairy food, the obtaining of plant material, as well as production costs, is definitely lower in the case of non-dairy products (Kandylis et al., 2016; Kumar, Venkata, \& Vijayendra, 2015).

In the view of this promising evidence for non-dairy fermented products with probiotic potential, an understanding of consumer food choices and their purchasing habits of this product category is necessary. To the best of the authors' knowledge, it will be the first time of studying the consumers' behaviour concerning exclusively fermented vegetable products with particular emphasis on the Polish market. Therefore, this paper attempts to fulfil the research gap concerning the food choices, purchasing and consumption of fermented vegetable products (both preserves and juices) in the realities of the Polish food market.

The paper is structured as follows: the first part includes an overview of the most common food choice theories. Following this, the research method and the results of empirical studies are presented. The paper terminates with a discussion and conclusion.

\section{Literature review}

The phenomenon of food choice theory should be seen as a complex and dynamic behaviour, which is subjected to constant changes. Therefore, according to the Food Standards Agency (FSA),

(...) food choices enable the selection of food products for consumption, which results from competing, reinforcing and interacting influences of a variety of factors. These range from the sensory, physiological and psychological responses of individual consumers to the interactions between social, environmental and economic influences, and include the variety of foods and the activities of the food industry to promote them. (Buttriss et al., 2004)

The scientific literature describes many theories concerning food choice behaviour - starting with learning, motivation theories and ending with the cognitive approach, which includes, among others, the theory of planned behaviour (Buttriss et al., 2004; Köster \& Mojet, 2007; Sato et al., 2020; Wadołowska, Babicz-Zielińska, \& Czarnocińska, 2008).

According to the learning theory, daily, food-related behaviour is strongly influenced by incidentally learning and memory processes, which is reinforced by simple associative and emotional conditioning. Food habit development begins in early infancy during the transition from mother's milk to solid foods and it is based on non-cognitive learning which includes such mechanisms as affective and classical conditioning, imprinting or imitation. On the other hand, in the later years of life food choices are affected by learning at the cognitive and conscious level, which may be caused by promotional and marketing activities, e.g. advertisement or food labelling (Köster \& Mojet, 2007). Food preferences and food choices can be explained also by 
motivation theories, which indicate that the consumption of particular food products is related to individual curiosity and search for stimulation (Köster \& Mojet, 2007).

In contrast to the above-mentioned theories, different scientific approaches emphasize the essence and importance of cognitive theories. The most popular of them - the theory of planned behaviour - presents the food selection process as a conscious strategy together with cognitive factors, which are based on the attitudes and beliefs of individuals (Köster \& Mojet, 2007). The theory of planned behaviour framework regarding food choices defines consumers action as a combination of three basic elements: 1) behavioural beliefs, which are based on beliefs about the outcome of an action, 2) normative beliefs, based on social norms and 3) control beliefs, which refer to perceived behavioural control (Lobb, Mazzocchi, \& Traill, 2007).

However, the majority of approaches presented in the literature are based on classic Shepherd propositions $(1989,1999)$. The researcher identified many factors influencing food choices and food consumption. Basically, these factors were divided into 3 main groups (food-related, consumer-related and environmental-related), which are summarized in Table 1.

Table 1. Factors affecting food choices

\begin{tabular}{|c|c|c|}
\hline Food-related factors & Consumer-related factors & Environmental-related factors \\
\hline $\begin{array}{l}\text { - taste, aroma, texture, visual } \\
\text { appearance } \\
\text { - packaging, accessibility, con- } \\
\text { venience } \\
\text { - nutritional composition of the } \\
\text { product }\end{array}$ & $\begin{array}{l}\text { - age, gender, education level } \\
\text { - personality, experience, mood } \\
\text { - satiety, hunger, appetite }\end{array}$ & $\begin{array}{l}\text { - } \text { marketing, prices, income, } \\
\text { brand } \\
\text { - beliefs, culture, religion } \\
\text { - fashion, society }\end{array}$ \\
\hline
\end{tabular}

Source: Authors' own study based on (Shepherd, 1989, 1999).

Different scientific reviews have highlighted the significance of social, environmental and psychological factors affecting individuals' food choices. Stroebele and De Castro (2004) indicated that the process of food choices depends on many different factors that influence each other. The first one includes physical surroundings, which involve the type of food, smells, temperature or even ambient light. Another determinant describes the time-related characteristics like meal frequency. Equally importantly, food choices are affected by factors called distractions, e.g. television, music. Furthermore, Cruwys, Bevelander, and Hermans (2015) pointed out that choosing food is strictly correlated with complex social modelling, which, in turn, implied that food intakes and choices are shaped by social norms.

In the present paper, the focus was set on the classic Shepherd approach, especially on the food related-factors, selected consumer-related factors (focusing on socio-demographic characteristics of participants), and some environmental-related factors, such as price and brand. This approach seems to be basic and crucial at the initial stage of the research, as well as being the starting point for future considerations. 


\section{Research methods}

Data collection was performed both through an online survey and a personal interview from April to May 2019 among Polish consumers. The questionnaire has been divided into 3 main parts with closed-ended and open-ended questions. The first part was an introduction and focused on general information regarding the consumption of fruit, vegetables and preserves (namely frequency and places of purchase). The second section focused on specific questions about fermented vegetable products, with a distinction between fermented vegetable juices and fermented preserves. The questions in this section concentrated on the following issues: the first thought regarding fermented vegetable products; the frequency of buying fermented vegetable products (juices and preserves); the places of purchase; the selection criteria, the advantages of this product category and the frequency of the consumption of selected fermented products. Finally, the third part included questions regarding the market offer of fermented juices. However, this section was not presented in the paper, due to the low number of respondents' responses compared to the previous parts.

Therefore, the present paper mainly focused on the second part of the study. The sample consisted of 205 adult participants, of whom $71.56 \%$ were women, who are mostly responsible for food purchasing for the households. Preliminary studies based on Polish Statistical Office data (from 2010 to 2018) regarding the consumption of vegetable preserves among the Polish population revealed that households with the reference person with higher education consume most of the mentioned product category. Therefore, in the present paper, the sample consisted of consumers characterized by higher levels of education. Table 2 summarizes some socio-demographic characteristics of the sample.

Descriptive statistics, one-way analysis of variance (ANOVA) and post-hoc Tukey's test were used in the data analysis. ANOVA was performed only for the issues that met the assumptions such as 1) the dependent variable was continuous, 2 ) the independent variable should consist of two or more categorical, independent groups, 3) independence of observations, 4) no significant outliers, 5) the dependent variable should be app. normally distributed for each category of the independent variable and 6) homogeneity of variance. The level of significance of the study was $p<0.05$. All calculations were performed using MS Excel and SPSS Statistics 26 (SPSS for Mac IOS: IMB SPSS Inc. New York, USA).

Table 2. Socio-demographic characteristic $(N=205)$

\begin{tabular}{|l|l|c|}
\hline \multirow{3}{*}{ Gender } & & Percentage of respondents \\
\cline { 2 - 3 } & Female & 72.20 \\
\cline { 2 - 3 } Age & Male & 27.80 \\
\hline \multirow{4}{*}{ Age } & $21-30$ & 42.44 \\
\cline { 2 - 3 } & $31-40$ & 25.37 \\
\cline { 2 - 3 } & $41-50$ & 18.05 \\
\cline { 2 - 3 } & $51-60$ & 10.73 \\
\cline { 2 - 3 } & Above 60 & 3.41 \\
\hline
\end{tabular}


Pobrane z czasopisma Annales H - Oeconomia http://oeconomia.annales.umcs.pl Data: 26/04/2023 11:34:20

\begin{tabular}{|l|l|c|}
\hline \multirow{4}{*}{$\begin{array}{l}\text { Material status (the national } \\
\text { average: 3,450 PLN) }\end{array}$} & Definitely below the national average & 9.76 \\
\cline { 2 - 3 } & Below the national average & 27.80 \\
\cline { 2 - 3 } & The national average & 30.24 \\
\cline { 2 - 3 } & Above the national average & 23.90 \\
\cline { 2 - 3 } & Definitely above the national average & 8.29 \\
\hline \multirow{5}{*}{ Place of residence } & Traditional village & 4.39 \\
\cline { 2 - 3 } & Village by the city & 11.22 \\
\cline { 2 - 3 } & City with below 20,000 citizens & 9.76 \\
\cline { 2 - 3 } & City with 20 to 99,000 citizens & 4.88 \\
\cline { 2 - 3 } & City with 100 to 199,000 citizens & 2.44 \\
\cline { 2 - 3 } & City with 200 to 499,000 citizens & 10.24 \\
\cline { 2 - 3 } & City with over 500,000 citizens & 57.07 \\
\hline
\end{tabular}

Source: Authors' own study.

\section{Results}

Food choices regarding fermented vegetable products on the Polish market are scarcely recognized in the literature. The conducted research allowed us to understand these choices, and provided new insight regarding the perception of fermented preserves and shopping habits among Polish society.

In the present paper, in the first questions, the respondents were asked to present their first thought regarding fermented vegetable products. Consequently, the responses were grouped in four main categories, which present as follows: 1 . Sensory feelings, 2. Properties, 3. Product category and 4. Processes. All responses have been summarized in Table 3. The indications presented in the first group were related to the taste and external appearance of fermented vegetable products. While the second group included expressions concerning various types of properties attributed to fermented food. The third and most numerous group contained product connotations. The last group of respondents indicated various types of processes.

Table 3. Respondents associations regarding fermented vegetable products

\begin{tabular}{|c|c|c|c|c|}
\hline Categories & Sensory feelings & Properties & Product category & Processes \\
\hline $\begin{array}{l}\text { Respondents' } \\
\text { first thoughts }\end{array}$ & $\begin{array}{l}\text { tasty, delicious, } \\
\text { sour, crispy, } \\
\text { salty }\end{array}$ & $\begin{array}{l}\text { healthy, pro-health, } \\
\text { immunity increase, } \\
\text { vitamin C, probiotics, } \\
\text { bacteria, low caloric } \\
\text { values, impact on gut } \\
\text { microbiota }\end{array}$ & $\begin{array}{l}\text { sauerkraut, pickled } \\
\text { cucumbers, fermented } \\
\text { beetroots, beetroot } \\
\text { sourdough, kimchi, } \\
\text { radishes, patisons, } \\
\text { mushrooms }\end{array}$ & $\begin{array}{l}\text { natural fermentation, } \\
\text { preserves, food preser- } \\
\text { vation, experiments in } \\
\text { the kitchen, jars }\end{array}$ \\
\hline
\end{tabular}

Source: Authors' own study.

Furthermore, the majority of respondents buy fermented vegetable-based preserves several times a month $(38 \%)$, whereas $25 \%$ of consumers declared purchase a few times a year and $21 \%$ admitted to purchasing once a week (Figure 1). 


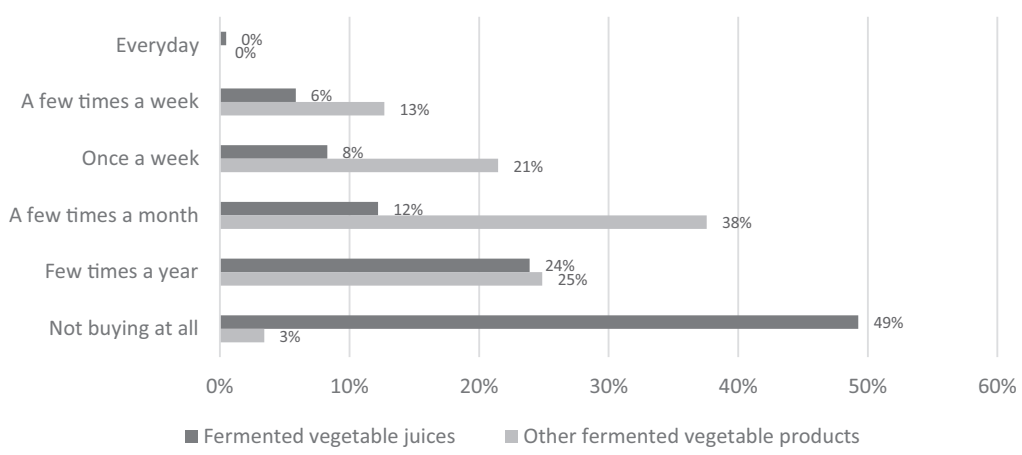

Figure 1. Frequency of purchase of fermented juices and other fermented vegetable products

Source: Authors' own study.

In the case of fermented vegetable juices, the purchasing habits of respondents are shaped differently. Basically, $49 \%$ of respondents declared that they do not buy fermented juices at all, $24 \%$ buy a few times a year and $12 \%$ of consumers purchase a few times a month. Comparing these two product categories, classic fermented vegetable preserves are definitely more favoured than fermented juices. This may be due to the fact that fermented juices are a relatively new category of products, while vegetable preserves are traditional and widespread food products in Poland. Additionally, preserves such as sauerkraut or pickled cucumbers are easily available in almost every grocery store, from local stores to supermarkets, as opposed to fermented juices.

The most common places of purchase of fermented vegetable products (both for juices and preserves) by surveyed consumers are discount stores, like Lidl or Biedronka ( $44 \%$ for preserves; $21 \%$ for juices), supermarkets ( $40 \%$ for preserves and $25 \%$ for juices) and local markets ( $40 \%$ for preserves and $18 \%$ for juices) (Figure 2 ).

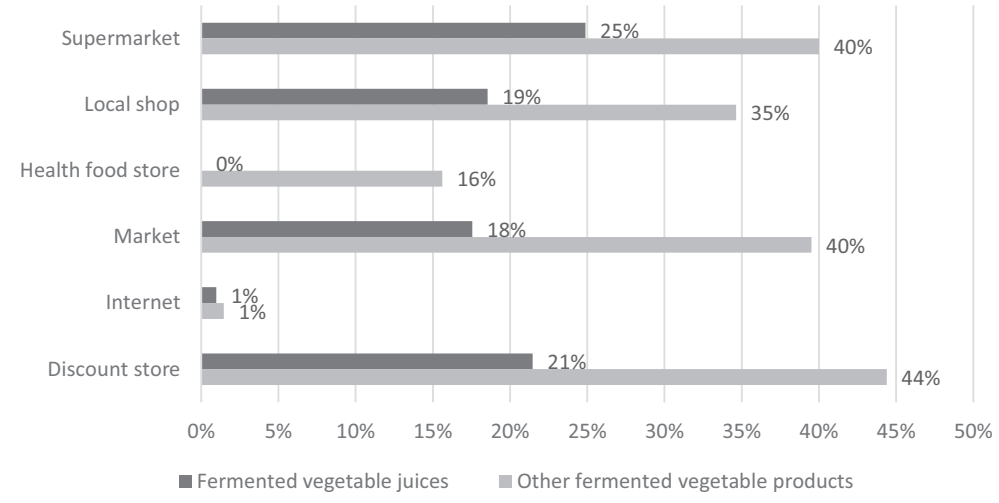

Figure 2. Place of purchase of fermented vegetable products 
This is most likely caused by easy access to stores and the multitude of products offered in one place. The purchase of fermented vegetable juices and fermented preserves in local stores declared by $19 \%$ and $35 \%$ of respondents, respectively. Despite the general growing trend in online shopping, the purchase of presented product categories is basically not practised.

Respondents' answers allowed to establish the most important advantages of fermented vegetable products (Figure 3).

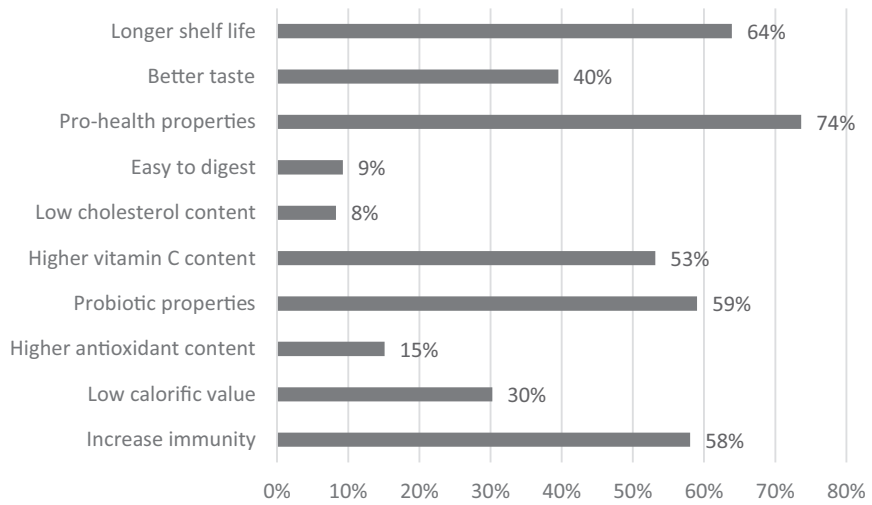

Figure 3. The advantages of fermented vegetable products

Source: Authors' own study.

According to the surveyed consumers, the most frequently indicated feature is widely understood "pro-health properties" with an indication on the level of $74 \%$. In addition, this feature is associated with further respondents' indications regarding the impact of consumption of fermented food on the human body. 59\% and $58 \%$ of respondents mentioned that this product category would be beneficial due to its ability to increase immunity and provide probiotic properties, respectively. Also, higher vitamin $\mathrm{C}$ content was mentioned by $53 \%$ of respondents. Thus, this research indicated that the main characteristics, which respondents identified with fermented foods are mainly positive effects on human health. Relatively less frequently, the respondents pointed to a better taste (40\%) and low calorific value (30\%). They found higher antioxidant activity, low cholesterol content and the possibility to easily digest to be the least important advantages among the others.

Another issue presented in this paper was the frequency of consumption of various fermented vegetable products available on the Polish market, i.e. juices (Figure 4) and preserves (Figure 5).

Data analysis revealed that preserves are consumed much more often in comparison to juices. According to the respondents, the most commonly consumed fermented juices, with varying frequency, were those made of cabbages, cucumbers and beetroots. Up to $94 \%$ and $90 \%$ of respondents do not consume fermented juices 
Pobrane z czasopisma Annales H - Oeconomia http://oeconomia.annales.umcs.pl

Data: 26/04/2023 11:34:20

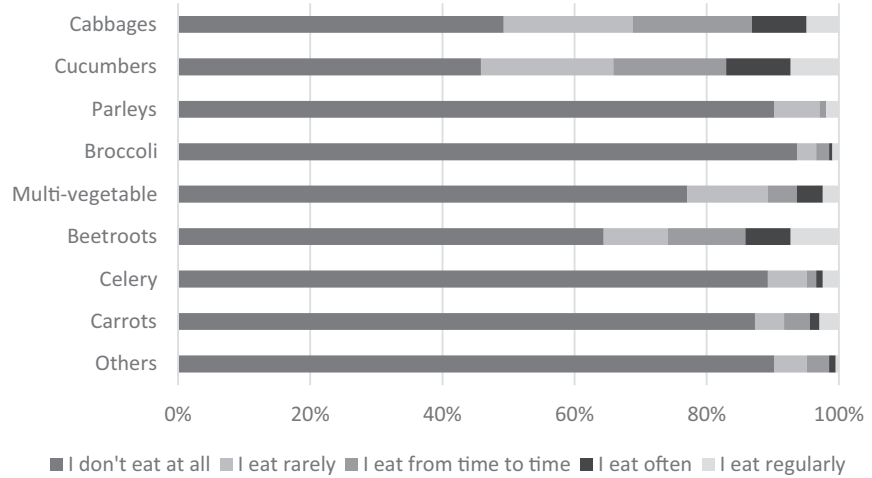

Figure 4. The frequency of consumption of fermented vegetable juices

Source: Authors' own study.

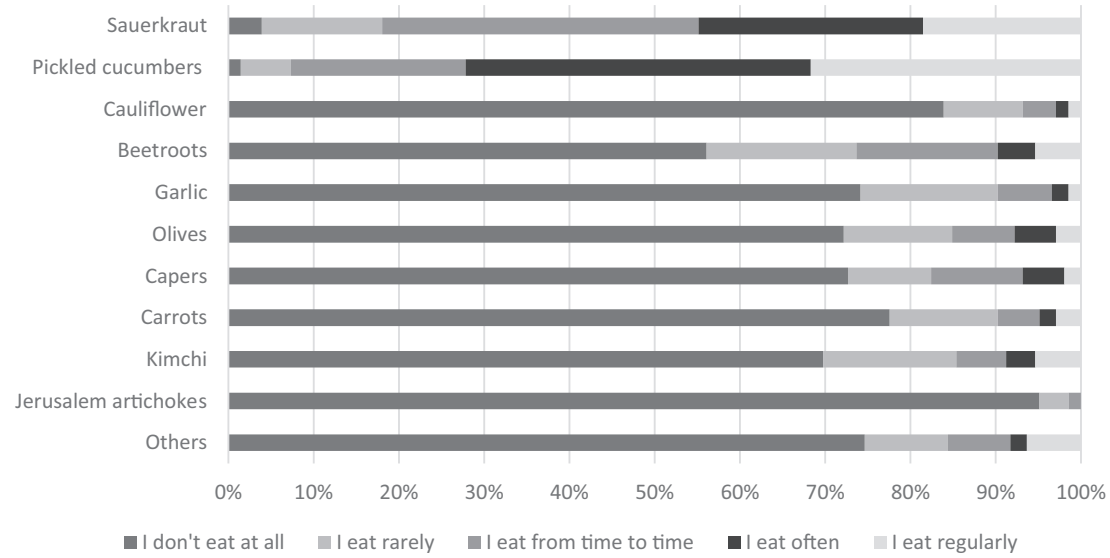

Figure 5. The frequency of consumption of fermented vegetables preserves

Source: Authors' own study.

made from broccoli and parleys, at all. On the contrary to fermented juices, preserves are eaten more frequently. Among fermented preserves, unquestionably sauerkraut, pickled cucumbers and beetroots are eaten relatively regularly by the respondents. $37 \%$ of the studied group consume sauerkraut from time to time, while $40 \%$ of them claimed to consume pickled cucumbers often and $32 \%$ eat regularly. Despite the fact that the consumption of pickled beetroots is less common, $18 \%$ of respondents declared eating this product category rarely and $17 \%$ - from time to time. On the opposite side, cauliflowers and Jerusalem artichokes preserves are among the least frequently consumed and common products.

A one-way ANOVA was conducted to compare the effect of the age group of respondents on the frequency of consumption of selected fermented vegetable pre- 
serves. The results are presented in Table 4 . There were statistically significant differences between groups, as determined by ANOVA $[\mathrm{F}(4.200)=2.995, p=0.020$ for the frequency of consumption of sauerkraut and $\mathrm{F}(4.200)=5.253, p=0.000$ for the frequency of consumption of pickled beetroots]. In the case of sauerkraut consumption, the post-hoc comparison performed with the use of Tukey's test indicated that the mean score for an age group ranging from 21 to 30 years old $(\mathrm{M}=$ $0.65, \mathrm{SD}=0.21)$ was significantly different from the age group stretching between 41 and 50 years old. Tukey's test performed for the frequency of pickled beetroots consumption revealed that the mean score for the age group of 21 to 30 years old was significantly different from those of 41 to $50(\mathrm{M}=0.92, \mathrm{SD}=0.22)$ and from 51 to 60 years old $(\mathrm{M}=0.74, \mathrm{SD}=0.26)$.

Table 4. One-way ANOVA for age groups of respondents across the frequency of consumption of selected fermented vegetable preserves (sauerkraut and beetroots)

\begin{tabular}{|l|l|c|c|c|c|c|}
\hline Product & & Sum of squares & Df & Mean square & F & Sig. \\
\hline \multirow{4}{*}{ Sauerkraut } & Between groups & 13.099 & 4 & 3.275 & 2.995 & .020 \\
\cline { 2 - 7 } & Within groups & 218.658 & 200 & 1.093 & & \\
\cline { 2 - 7 } & Total & 231.756 & 204 & & & Sig. \\
\hline \multirow{3}{*}{ Beetroots } & & Sum of squares & Df & Mean square & F & .000 \\
\cline { 2 - 7 } & Between groups & 26.584 & 4 & 6.646 & 5.253 & \\
\cline { 2 - 7 } & Within groups & 253.026 & 200 & 1.265 & & \\
\hline
\end{tabular}

Source: Authors' own study.

The study revealed the most important factors affecting the food choices concerning fermented vegetable products, which are presented in Figure 6.

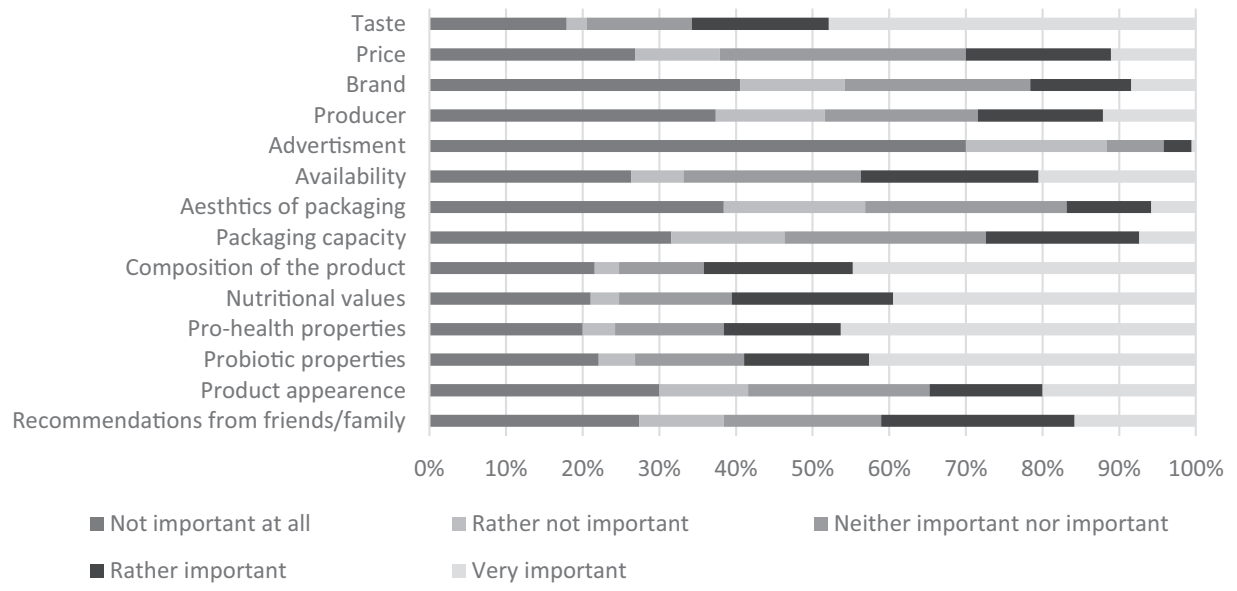

Figure 6. The most important factors affecting fermented vegetable juices choices 
Since more than half of the respondents declared that they do not buy fermented vegetable juices, the results were presented only for preserves. Moreover, comparing these two product categories, the results for juices were quite similar. The highest-rated criteria for selecting mentioned products belonged both to the sensory and health categories. $62 \%$ of respondents declared that taste is a very important criterion in food choices. Further criteria, concerned mainly the positive impact of consumption on the human body, indicated that nutritional value was very important to $44 \%$ of respondents, the general perception of fermented preserves as pro-health was declared by $45 \%$, and $43 \%$ of respondents stated that probiotic properties are crucial. The product composition in food choice proved to be an equally important factor for $50 \%$ of respondents. On the contrary, 2/3 of those sampled indicated that advertisement was not important at all. Also, brand, producer and aesthetic of packaging were the least important factors influencing the respondents' decisions regarding food choices.

Additionally, the one-way ANOVA was performed to compare the impact of the age group of respondents on the most important criteria for choosing fermented vegetable preserves (Table 5). There were statistically significant differences between groups, as determined by ANOVA $[\mathrm{F}(4.200)=2.429, p=0.49$ for brand $]$. In the case of brand criterion, the post-hoc Tukey's test found that the mean score for the age group ranging from 21 to 30 years old was significantly different from the age group between 41 to 50 years old.

Table 5. One-way ANOVA for age groups of respondents across the most important criteria for choosing fermented vegetable preserves (brand)

\begin{tabular}{|c|l|c|r|r|r|c|}
\hline Criteria & & Sum of squares & Df & Mean square & F & Sig. \\
\hline \multirow{4}{*}{ Brand } & Between groups & 18.576 & 4 & 4.644 & 2.429 & .049 \\
\cline { 2 - 7 } & Within groups & 382.467 & 200 & 1.912 & & \\
\cline { 2 - 7 } & Total & 401.044 & 204 & & & \\
\hline
\end{tabular}

Source: Authors' own study.

As far as the managerial implications are concerned, the study may be insightful for the managers considering different target markets. Because of the relatively lower frequency of consumption of sauerkraut and pickled beetroots in the age group ranging from 21 to 30 years old in relation to that stretching between 41 and 50 years old (and 51 to 60 years old in the case of pickled beetroots), a reasonable tactic would be to target middle-aged (and senior) customers. In the same vein, the study demonstrated that this target group is more sensitive to the recognised brand when it comes to the criteria for choosing fermented vegetable preserves. Consequently, paying particular attention to brand and targeting middle-aged customers may be treated as a promising market policy. 


\section{Discussion}

Considering the specific characteristics of the Polish functional market, it seems that the interest in the consumption of fermented vegetable products with potential probiotic properties fits in with new trends on the food market. It should be emphasized that frequent and regular consumption of products such as sauerkraut, pickled cucumbers or beetroots results mainly from the Polish tradition and is strongly rooted in Polish society. While the consumption of other products like kimchi is most likely caused by changing food trends, easy access to foreign products as well as greater awareness of pro-health properties among potential consumers. Wilczak (2019) reached similar conclusions, demonstrating that respondents from Poland, Germany and Croatia consume fermented vegetables much more often in comparison to other European countries like Spain or Great Britain. It is, as the author pointed out, directly associated with the characteristics of traditional preserves and eating habits of these nations. Furthermore, the study revealed, as in the present article, that about half of the respondents from Poland, Germany and Croatia declared the intake frequency of fermented vegetables several times a month (Wilczak, 2019).

Similarly to the present study, the research conducted by Wadołowska et al. (2008) regarding Poles' food choices revealed that the most influencing factors were sensory features, especially taste. However, contrary to current research, the authors presented that health aspects influenced moderately on consumers' food choices. Most likely, the differences in the significance of factors affecting the choice of food may result from the limited group of food products in this paper - their research focused on a much larger range of products including fruits, vegetables, meat, fish, sweets dairy and cereal products. Also, Wilczak's (2019) research proved that the most important factors influencing the consumption of fermented vegetables were taste quality and secondly - the health-promoting properties.

According to the research performed by Kraus, Annunziata, and Vecchio (2017), concerning the motivations for the consumption of functional foods, the authors demonstrated that age, gender and level of education influenced the decision to purchase functional products. For example, the authors showed that essentially women in contrast to men paid more attention to functional components of products, as well as their nutritional value, quality and freshness. Studies in the present research also indicated that age statistically significantly affected the consumption of sauerkraut and fermented beetroots. Generally, studies on differences in socio-demographic factors influencing the food choices of functional products are necessary and fundamental research and constitute a starting point for further considerations. 


\section{Conclusions}

The growing importance of non-dairy fermented products based on vegetables, like juices or preserves requires the expansion of knowledge and basic research concerning consumption, purchasing habits and factors underlying the food choices of this product category. The current research contributes to the existing body of knowledge in that it provides empirical findings concerning consumers' behaviour on the fermented vegetable market in the Polish context. This article indicated that $3 / 4$ of the respondents associated pickled vegetables with health-promoting properties, including probiotic properties, higher vitamin $\mathrm{C}$ content and the possibility to increase immunity. In addition, it was revealed that frequent consumption of fermented preserves include mainly sauerkraut, pickled cucumbers and beetroots. The most important factors influencing the choice of fermented products have been identified. According to the respondents, the following aspects were distinguished: taste, general perception as pro-health products, nutritional values, probiotic properties and product composition.

However, the study was not free of limitations. Future research would benefit, for the first, from a larger research sample, for example, including the respondents from a wider age range, and the respondents with different levels of education. Such an approach would allow a more accurate and comprehensive examination of consumer trends and behaviour towards fermented vegetable products. Secondly, future research directions should also contain a more diverse range of products, including fermented fruit-based products. Thirdly, qualitative research would be an essential complement to the present study to reinforce the legitimacy of our findings. Qualitative methods, like focus groups or in-depth interviews, enable the insight and in-depth understanding of the issue from a different perspective. Besides, this study was conducted in the context of only one country, thus, future research could be extended to other European countries.

\section{Research funding}

This work was supported by the project: "Integrated Development Program of the Poznań University of Economics and Business" no. WND-POWR.03.05.0000-Z011/17 which is co-financed by the European Union under the Operational Program "Knowledge Education Development 2014-2020". 


\section{References}

Ávila, B.P., da Rosa, P.P., Fernandes, T.A., Chesini, R.G., Sedrez, P.A., de Oliveira, A.P.T., ... Roll, V.F.B. (2020). Analysis of the Perception and Behaviour of Consumers Regarding Probiotic Dairy Products. International Dairy Journal, 106. https://doi.org/10.1016/j.idairyj.2020.104703

Buttriss, J., Stanner, S., McKevith, B., Nugent, A.P., Kelly, C., Phillips, F., \& Theobald, H.E. (2004). Successful Ways to Modify Food Choice: Lessons from the Literature. Nutrition Bulletin, 29(4), 333-343. https://doi.org/10.1111/j.1467-3010.2004.00462.x

Cruwys, T., Bevelander, K.E., \& Hermans, R.C.J. (2015). Social Modeling of Eating: A Review of When and Why Social Influence Affects Food Intake and Choice. Appetite, 86, 3-18. https://doi.org/10.1016/j.appet.2014.08.035

Filannino, P., Azzi, L., Cavoski, I., Vincentini, O., Rizzello, C.G., Gobbetti, M., \& Di Cagno, R. (2013). Exploitation of the Health-Promoting and Sensory Properties of Organic Pomegranate (Punica granatum L.) Juice Through Lactic Acid Fermentation. International Journal of Food Microbiology, 163(2-3), 184-192. https://doi.org/10.1016/j.ijfoodmicro.2013.03.002

Granato, D., Branco, G.F., Nazzaro, F., Cruz, A.G., \& Faria, J.A.F. (2010). Functional Foods and Nondairy Probiotic Food Development: Trends, Concepts, and Products. Comprehensive Reviews in Food Science and Food Safety, 9(3), 292-302. https://doi.org/10.1111/j.1541-4337.2010.00110.x

Hutkins, R. (2019). Microbiology and Technology of Fermented Foods. Hoboken: Wiley \& Sons.

Kandylis, P., Pissaridi, K., Bekatorou, A., Kanellaki, M., \& Koutinas, A.A. (2016). Dairy and Non-Dairy Probiotic Beverages. Current Opinion in Food Science, 7, 58-63. https://doi.org/10.1016/j.cofs.2015.11.012

Köster, E.P., \& Mojet, J. (2007). Theories of Food Choice Development. Understanding Consumers of Food Products, 93-124. https://doi.org/10.1533/9781845692506.1.93

Kraus, A., Annunziata, A., \& Vecchio, R. (2017). Sociodemographic Factors Differentiating the Consumer and the Motivations for Functional Food Consumption. Journal of the American College of Nutrition, 36(2), 116-126. https://doi.org/10.1080/07315724.2016.1228489

Kumar, B.V., Venkata, S., \& Vijayendra, N. (2015). Trends in Dairy and Non-Dairy Probiotic Products a Review. Journal of Food Science and Technology, 52(10), 6112-6124. https://doi.org/10.1007/s13197-015-1795-2

Lobb, A.E., Mazzocchi, M., \& Traill, W.B. (2007). Modelling Risk Perception and Trust in Food Safety Information Within the Theory of Planned Behaviour. Food Quality and Preference, 18(2), 384-395. https://doi.org/10.1016/j.foodqual.2006.04.004

Mazlan, F.A., Suffian, M., \& Sharifuddin, Y. (2015). Biotransformation of Momordica Charantia Fresh Juice by Lactobacillus plantarum BET003 and Its Putative Anti-Diabetic Potential. PeerJ, 2015(10), 1-18. https://doi.org/10.7717/peerj.1376

Panghal, A., Janghu, S., Virkar, K., Gat, Y., Kumar, V., \& Chhikara, N. (2018). Potential Non-Dairy Probiotic Products - a Healthy Approach. Food Bioscience, 21, 80-89.

https://doi.org/10.1016/j.fbio.2017.12.003

Ranadheera, C.S., Vidanarachchi, J.K., Rocha, R.S., Cruz, A.G., \& Ajlouni, S. (2017). Probiotic Delivery Through Fermentation: Dairy vs. Non-Dairy Beverages. Fermentation, 3(4), 1-17. https://doi.org/10.3390/fermentation3040067

Sato, P. de M., Couto, M.T., Wells, J., Cardoso, M.A., Devakumar, D., \& Scagliusi, F.B. (2020). Mothers' Food Choices and Consumption of Ultra-Processed Foods in the Brazilian Amazon: A Grounded Theory Study. Appetite, 148, 104602. https://doi.org/10.1016/j.appet.2020.104602

Shepherd, R. (1989). Factors Influencing Food Preferences and Choices. In Handbook of Psychophysiology of Human Eating (pp. 3-24). New York: Wiley \& Sons.

Shepherd, R. (1999). Social Determinants of Food Choice. Proceedings of the Nutrition Society, 58(4), 807-812. https://doi.org/10.1017/S0029665199001093 
Pobrane z czasopisma Annales $\mathrm{H}$ - Oeconomia http://oeconomia.annales.umcs.pl

Data: 26/04/2023 11:34:20

CONSUMER BEHAVIOUR ON THE NON-DAIRY FERMENTED MARKET

Stroebele, N., \& De Castro, J.M. (2004). Effect of Ambience on Food Intake and Food Choice. Nutrition, 20(9), 821-838. https://doi.org/10.1016/j.nut.2004.05.012

Wadołowska, L., Babicz-Zielińska, E., \& Czarnocińska, J. (2008). Food Choice Models and Their Relation with Food Preferences and Eating Frequency in the Polish Population: POFPRES Study. Food Policy, 33(2), 122-134. https://doi.org/10.1016/j.foodpol.2007.08.001

Wilczak, M. (2019). Postawy i zachowania konsumentów wybranych krajów europejskich wobec produktów fermentowanych. In W. Truszkowski \& P.R. Sosna (red.), Uwarunkowania bezpieczeństwa i jakości żywności w Polsce (pp. 29-39). Olsztyn: UWM.

Ye, J.-H., Huang, L.-Y., Terefe, N.S., \& Augustin, M.A. (2019). Fermentation-Based Biotransformation of Glucosinolates, Phenolics and Sugars in Retorted Broccoli Puree by Lactic Acid Bacteria. Food Chemistry, 286, 616-623. https://doi.org/10.1016/j.foodchem.2019.02.030 